\title{
PENGGUNAAN MODEL INKUIRI SOSIAL UNTUK MENINGKATKAN KECERDASAN SOSIAL SISWA KELAS V
}

\author{
Samuel Patra Ritiauw* \\ Elsinora Mahananingtyas \\ Titin Ode
}

\author{
Prodi Pendidikan Guru Sekolah Dasar, Fakultas Keguruan dan Ilmu Pendidikan, Universitas Pattimura \\ Jl. Dr. Tamaela, Ambon \\ *E-mail: pritiauw@gmail.com
}

Artikel diterima: 13 Februari 2021; disetujui: 11 Mei 2021

\begin{abstract}
This study aims to examine the application of social inquiry models related to increasing social intelligence in social studies subjects in an elementary school. This study used a quantitative approach with a quasi-experimental research type with a One Group PretestPostest design. The result shows that the five indicators of social intelligence developed are selfawareness, working with others, communicating, empathizing, and problem-solving. All indicators have been successfully improved by implementing the social model of inquiry on 25 fifth-grade students of MI Salman Al-Farisi. Of the five indicators of social intelligence developed, problem-solving intelligence is the indicator of social intelligence with the highest increase compared to the empathic indicator, which is in the low criterion, while other indicators are in the medium category.
\end{abstract}

Keywords: social inquiry model; social intelligence; elementary school; elementary school social studies

\begin{abstract}
Abstrak: Penelitian bertujuan menguji penerapan model inkuiri sosial terkait dengan peningkatan kecerdasan sosial pada Mata Pelajaran IPS di SD. Penelitian ini menggunakan pendekatan kuantitatif dengan jenis penelitian eksperimen semu dengan desain One Group Pretest-Postest. Hasil penelitian menunjukkan bahwa kelima indikator kecerdasan sosial yang dikembangkan yakni kesadaran diri, mampu bekerjasama dengan orang lain, mampu berkomunikasi, berempati dan pemecahan masalah, berhasil ditingkatkan melalui implementasi model sosial inkuiri pada 25 siswa kelas V MI Salman Al-Farisi. Dari kelima indikator kecerdasan sosial yang dikembangkan, kecerdasan memecahkan masalah merupakan indikator kecerdasan sosial yang paling tinggi peningkatannya jika dibandingkan dengan indikator berempati yang berada pada kriteria rendah, sementara indikator lainnya berada pada kategori sedang.
\end{abstract}

Kata kunci: model inkuiri sosial; kecerdasan sosial, sekolah dasar; IPS SD

\section{PENDAHULUAN}

Setiap anak memiliki karakteristik yang berbeda satu dengan yang lainnya, sehingga proses mendidik setiap anak yang memiliki perbedaan karakteristik memerlukan perlakuan yang berbeda pula. Karena itu, guru dan orang tua harus memahami perilaku dan karakter anak dengan baik. 
Nasehudin (2016) menjelaskan bahwa anak pintar umumnya diketahui dari nilai rapor dan hasil belajar yang bagus, namun hal ini bukan menjadi salah satu karakteristik dominan yang dimiliki setiap anak untuk menuju kesuksesan. Menurut Pradana \& Masyitoh (2018), kesuksesan hidup seorang anak diperoleh dari kecerdasan intelektual sebesar 20\%, sementara kecerdasan sosial, emosional, dan spiritual menyumbang sebanyak $80 \%$ pada kesuksesan hidup. Hasil penelitian tersebut memiliki kesesuaian dengan hasil penelitian UNICEF dalam (Surahman \& Mukminan, 2017) menyatakan bahwa munculnya kritik terhadap pendidikan di sekolah-sekolah disebabkan karena pendidikan di sekolah lebih mengutamakan aspek pengetahuan siswa jika dibandingkan dengan aspek sikap siswa.

El-Banjary (2013) menyatakan jika ada unsur yang dianggap sebagai faktor penentu kesuksesan atau keberhasilan seorang anak dalam ranah menuju masa yang akan datang, maka itu adalah attitude (sikap). Aspek sikap dalam implementasi pendidikan IPS di sekolah dasar, memegang peranan penting dalam mewujudkan warganegara yang baik. Hasan (2010) menjelaskan bahwa tujuan Pendidikan IPS dalam Kurikulum 2013 antara lain terkait dengan sikap peduli, bertanggung jawab, rasa ingin tahu, kemampuan inkuiri, kemampuan pengambilan keputusan, berpikir kritis, kreatif, inovatif dan disiplin.

Untuk mewujudkan tujuan pendidikan IPS di Indonesia, maka peneliti menggunakan model inkuiri sosial yang bertujuan untuk meningkatkan kecerdasan sosial siswa kelas V MI Salman AlFarisi Liang. Menurut Villagonzalo dalam (Alfina dkk., 2018) menjelaskan bahwa inkuiri sosial adalah pembelajaran yang berbasis eksperimen, berpusat pada filsafat dan ilmu pedagogi yang artinya seluruh siswa saling bekerja dalam kelompok kecil untuk mengikuti penyelidikan secara terpandu, melalui bahan yang telah dipersiapkan untuk mengarahkan dan membimbing siswa mengkonstruksi kembali pengetahuan ilmiah dan sosial mereka. Inkuiri memberikan pengalaman nyata dan pembelajaran aktif untuk memberikan kesempatan kepada siswa untuk mengkonstruksi pengetahuan sehingga siswa dapat mengembangkan keterampilan problem solving, sehingga memungkinkan para siswa menjadi pembelajar sepanjang hayat. Mempelajari inkuiri dapat melatih proses memperoleh pengetahuan yang benar dengan cara sistematis, misalnya siswa diminta mengumpulkan bukti-bukti yang telah dimilikinya lalu diberikan pertanyaan untuk mengembangkan kesimpulan (Salam, 2017).

Inkuiri juga dikembangkan melalui teori Jean Piaget dengan teori konstruktivis kognitif dan teori Vygotsky yang merumuskan teori konstruktivisme sosial. Jean Piaget meyakini bahwa belajar adalah proses menemukan sendiri, dimana seseorang benar-benar mengalami secara langsung, berinteraksi dan mengamati lingkungan sekitarnya untuk mempelajari sesuatu. Sementara (Vygotsky, 1978) meyakini bahwa perkembangan kognitif seseorang adalah hasil dari interaksi dengan lingkungan dan masyarakatnya. Vygotsky yakin bahwa aspek sosial dan budaya membantu 
proses kognitif seseorang. Lev Vygotsky berhasil mengembangkan teori konstruktivisme sosial (Utami, 2016). Santrock dalam (Mahananingtyas, 2018, hlm. 36) menjelaskan bahwa dalam teori konstruktivis sosial, Vygotsky menekankan bahwa siswa membangun pengetahuannya dengan berinteraksi sosial secara aktif dengan orang lain. Pengetahuan siswa dipengaruhi oleh kultur tempat dimana siswa tinggal, dari segi keyakinan, adat istiadat, bahasa, dan keterampilan yang diajarkan oleh lingkungan tempat tinggal siswa tersebut, sehingga guru harus memberikan banyak ruang bagi siswa untuk membangun pengetahuan bersama-sama melalui interaksi belajar di sekolah (Mahananingtyas, 2018).

Jean Piaget mengasumsikan bahwa semua siswa tumbuh dan mengikuti urutan perkembangan yang sama, namun pertumbuhan setiap siswa berada pada kecepatan yang berbeda-beda. Sebagian besar perkembangan kognitif siswa bergantung pada seberapa jauh siswa merubah dan berpartisipasi aktif dalam lingkungan sekitarnya. Teori Piaget dan Vygotsky memiliki persamaan yaitu peran guru sebagai fasilitator, bukan sebagai pemberi informasi (Ritiauw \& Salamor, 2016). Persamaan ini memiliki kaitan erat dengan implementasi kurikulum 2013 yang mewajibkan terjadinya studentcentered learning pada proses pembelajarannya di kelas. Kurikulum 2013 menggunakan pendekatan scientific yang memungkinkan siswa untuk dapat melakukan proses ilmiah yaitu mengamati, menanya, menalar/mengasosiasi, mencoba/mencari informasi, dan mengkomunikasikan. Schunk (dalam Ritiauw \& Salamor, 2016) menjelaskan hal ini sesuai dengan teori belajar konstruktivis sosial dari Vygotsky yang lebih menekankan pada interaksi sosial yang harus diwujudkan dalam proses belajar di kelas.

Teori Vygotsky dalam pendidikan memiliki dua implikasi utama (Ritiauw \& Salamor, 2016). Pertama, siswa dapat menyelesaikan tugas-tugas yang sulit dan dapat menemukan model-model pemecahan masalah yang efektif di dalam masing-masing Zone Proximal Development (Zona Perkembangan Proksimal) mereka, sehingga diperlukan penataan kelas dan bentuk pembelajaran kooperatif antar siswa. Kedua, teori Vygotsky dalam pengajaran menekankan adanya scaffolding. Siswa perlu bantuan guru untuk belajar dan bekerja secara berkelompok sehingga siswa dapat saling berinteraksi satu dengan yang lain yang pada akhirnya siswa dapat bertanggung jawab dengan pembelajarannya sendiri.

Model pembelajaran inkuiri sosial memiliki tujuan untuk mengubah kegiatan pembelajaran konvensional yang lebih berpusat kepada guru, kepada pembelajaran yang lebih inovatif dan menjadikan siswa sebagai pusat pembelajaran (student oriented). Hal ini sesuai dengan orientasi pembelajaran IPS yang dikemukakan Artana, dkk, (dalam Alfina dkk., 2018) bahwa dalam pembelajaran IPS harus dilakukan dengan inkuiri sosial (sosial inquiry) untuk meningkatkan kemampuan berinteraksi siswa dalam bersosialisasi dengan teman belajarnya guna bekal kehidupan bermasyarakat. 
Kusumawati \& Manutede (2018) menjelaskan bahwa setiap orang belum tentu memiliki kecerdasan sosial, tetapi untuk memilikinya ada pembelajaran sosial yang harus dikembangkan terutama dalam dunia Pendidikan. Kecerdasan sosial yang dimaksudkan dalam penelitian ini adalah memfokuskan beberapa bentuk kecerdasan yang dapat diyakini mampu mengembangkan kecerdasan sosial seseorang, diantaranya ada lima aspek yaitu kesadaran diri, mampu bekerjasama dengan orang lain, mampu berkomunikasi, berempati, dan mampu memecahkan masalah.

Pertama, yaitu aspek kesadaran diri (self awareness) adalah perhatian kepada seseorang untuk memahami keadaan melalui proses refleksi diri secara sadar untuk memikirkan hal-hal yang terjadi yang merupakan pengalaman dalam dirinya. Adapun Prasetyo (dalam Kusumaningrum, 2016) menyatakan self awareness adalah keadaan saat seseorang menyadari akan emosi yang dialaminya serta pikiran yang membentuk luapan emosi tersebut.

Kedua, yaitu aspek mampu bekerjasama dengan orang lain, menurut Thomas dan Johnson dalam (Kowendha, 2016) kerjasama yaitu makhluk hidup yang saling berkelompok saling kenal ataupun tidak kenal. Kerja sama adalah proses berkelompok dimana para anggotanya saling mendukung untuk mencapai suatu kesepakatan. Tempat yang sangat baik untuk membangun kemampuan berkelompok (tim) yaitu ruang kelas yang kemudian dibutuhkan dalam kehidupan.

Aspek ketiga yaitu empati. Menurut Kamus Besar Bahasa Indonesia, empati berarti perasaan ikut memahami dan merasakan apa yang dirasakan oleh orang lain. Pengertian ini hampir sama dengan Theory of Mind (ToM) dimana seseorang memasukkan sudut pandang atau perspektif orang lain ke dalam dirinya dan menggunakannya untuk memahami kondisi, jalan pikiran orang lain, dan situasi. Menurut Ramdhani (2016) rasa kasih sayang, kepedulian dan rasa ingin menolong sesama bersumber dari rasa empati pada diri seseorang.

Aspek keempat yaitu komunikasi. Komunikasi yaitu proses penyampaian pesan oleh seseorang kepada orang lain untuk memberi informasi, pendapat, dan perilaku, baik langsung (komunikasi tatap muka) maupun tidak langsung (komunikasi melalui media). Adapun aspek terakhir yaitu aspek mampu memecahkan masalah. Anak yang memiliki kecerdasan interpersonal yang tinggi akan memiliki keterampilan untuk memecahkan masalah antar pribadi secara efektif, dibanding dengan anak yang kecerdasan interpersonalnya. Aspek ini wajib dimiliki oleh setiap siswa sebagai makhluk sosial, karena hampir setiap harinya siswa diperhadapkan dengan masalah baik yang dialami di sekolah, rumah maupun lingkungan sosial (tempat bermain) siswa tersebut.

Kelima aspek tersebut ada pada mata pelajaran Ilmu Pengetahuan Sosial (IPS) memiliki nilai inti yang berguna bagi masyarakat demokrasi. Menurut Susanti (2018), nilai inti ini meliputi nilai kepercayaan dan martabat setiap manusia, kebebasan individu, hak, keadilan untuk semua, disiplin, integritas, martabat buruh, keadilan sosial, toleransi beragama, patriotisme, percaya diri, dan rasa tanggung jawab serta persaudaraan. 
Pengembangan kelima aspek kecerdasan sosial melalui implementasi model pembelajaran inkuiri sosial pada siswa kelas V MI Salman Al-Farisi Liang, didasarkan pada hasil observasi peneliti di lapangan dimana memperlihatkan bahwa siswa memiliki kecerdasan sosial yang sangat minim. Minimnya kecerdasan sosial siswa dapat dibuktikan dengan kurang adanya kerjasama antara siswa, kurangnya kekompakkan dalam tim belajar, kurang adanya rasa empati terhadap siswa lain dalam belajar, serta masih ditemukan sifat emosional siswa yang belum terkontrol dengan baik, sehingga sering terjadi perdebatan juga perkelahian dan tidak ada satupun dari siswa yang dapat melerai.

Untuk mengembangkan penelitian ini, peneliti melakukan kajian terhadap beberapa hasil penelitian terdahulu diantaranya oleh Rahmawati (2016) dengan judul "Tingkat Kecerdasan Sosial Siswa Dalam Pembelajaran IPS Kelas V SDN Di Kecamatan Mejobo Kabupaten Kudus.” Hasil penelitian tersebut menunjukan bahwa tingkat kecerdasan sosial siswa dalam pembelajaran IPS Kelas V SDN di Kecamatan Mejobo Kabupaten Kudus termasuk dalam kategori sangat baik, artinya siswa selalu mempunyai kesadaran situasional, selalu mempunyai kemampuan membawa diri, selalu mempunyai autentisitas, selalu mempunyai clarity dan selalu mempunyai empati yang sangat baik dalam pembelajaran IPS Kelas V. Hasil penelitian yang lain dilakukan oleh Zakiah (2020) dengan judul penelitian "Hubungan Kecerdasan Sosial dan Hasil Belajar Siswa Kelas IV Sekolah Dasar." Penelitian tersebut menyimpulkan bahwa terdapat hubungan positif antara kecerdasan sosial dan hasil belajar. Hal tersebut mengindikasikan bahwa semakin tinggi kecerdasan sosial maka semakin tinggi hasil belajar siswa, begitu pula sebaliknya, semakin rendah kecerdasan sosial akan semakin rendah pula hasil belajar.

Hasil penelitian terdahulu yang telah dipaparkan memiliki perbedaan dengan yang peneliti kembangkan dimana terlihat dari penggunaan model pembelajaran inkuiri sebagai variabel $\mathrm{X}$ dan kecerdasan sosial siswa sebagai variabel Y. Selain perbedaan variabel penelitian, perbedaan yang sangat signifikan yakni lokasi penelitian ini bertempat pada salah satu pondok pesantren yang sangat dekat dengan nilai-nilai religius namun tidak memiliki korelasi dengan hasil observasi awal pada siswa kelas V MI Salman Al-Farisi Liang - Kabupaten Maluku Tengah. Oleh sebab itu penelitian ini bertujuan untuk menguji ada tidaknya pengaruh terkait penggunaan model inkuiri sosial terhadap peningkatan kecerdasan sosial siswa kelas V MI Salman Al Farisi, Liang.

\section{METODE}

Penelitian ini menggunakan metode penelitian eksperimen semu, yaitu metode penelitian yang variabel luarnya masih mempengaruhi terbentuknya variabel dependen. Alasan pemilihan metode penelitian eksperimen semu yaitu untuk mengetahui dan menyelidiki hubungan sebab akibat dari perlakuan model inkuiri sosial terhadap kecerdasan sosial. Sampel penelitian ini melibatkan siswa 
kelas V MI Salman Al-Farisi Liang tahun pelajaran 2019/2020 yang berjumlah 25 siswa dan dipilih berdasarkan tujuan tertentu (purposive sampling). Desain penelitian dilakukan dengan mengikuti pola pada Tabel 1.

Tabel 1. Rancangan Penelitian

\begin{tabular}{ccc}
\hline Pre-test & Perlakuan & Post-test \\
\hline $\mathrm{Q}_{1}$ & $\mathrm{X}$ & $\mathrm{Q}_{2}$ \\
\hline
\end{tabular}

Keterangan:

$\mathrm{Q}_{1}=$ hasil belajar tes awal sebelum perlakuan

$\mathrm{Q}_{2}=$ hasil belajar tes akhir setelah perlakuan

$\mathrm{X}=$ perlakuan

Metode pengumpulan data pada penelitian ini menggunakan teknik angket, observasi, dan dokumentasi. Instrumen yang digunakan pada penelitian ini terdiri dari angket, lembar penilaian guru dan siswa, dan dokumen. Angket yang digunakan dalam penelitian ini menggunakan skala likert yaitu lembar angket dengan skala lima. Alternatif jawaban ada 5 dengan kategori jawaban 'Sangat Setuju' (SS) dengan skor 5, 'Setuju' (S) dengan skor 4, 'Ragu-Ragu' (R) dengan skor 3, 'Tidak Setuju' (TS) dengan skor 2, dan 'Sangat Tidak Setuju' (STS) dengan skor 1. Lembar Penilaian yaitu suatu kegiatan untuk menilai proses belajar mengajar dengan cara mengamati tidak langsung atau langsung kegiatan yang sedang berlangsung yang pada penelitian ini dilakukan dengan mengobservasi guru dan siswa. Skala ceklis observasi yang digunakan menggunakan skala Guttman dengan dua pilihan 'Ya' yang bernilai 1 dan 'Tidak' yang bernilai 0. Dokumen yang digunakan dalam penelitian ini bertujuan untuk mendokumentasikan segala proses penelitian yang berupa foto ataupun video kegiatan tes awal, proses, dan tes akhir.

Teknik analisis data dalam penelitian ini yaitu teknik analisis data kuantitatif yaitu dengan mempergunakan dua teknik analisis data. Teknik analisis pertama yaitu menggunakan rumus NGain yang berfungsi untuk mengukur peningkatan kecerdasan sosial. Teknik analisis kedua yaitu analisis statistik deskriptif yang ditampilkan dalam bentuk persentase.

\section{Analisis Rumus N-Gain Ternormalisasi}

Menurut Hake (dalam Amiluddin \& Sugiman, 2016) skor N-gain $\langle$ g $\rangle$ yang dapat diartikan sebagai pembanding skor $\mathrm{N}$-gain aktual dengan skor N-gain yang paling maksimal. Rumus N-gain yang digunakan yaitu sebagai berikut.

$$
\begin{array}{ll}
\qquad \text { N-Gain }= & \text { Skor Posttest }- \text { Skor Pretest } \\
\text { Keterangan : } & \text { Skor Ideal }- \text { Skor Pretest } \\
\text { Skor posttest } & =\text { skor akhir } \\
\text { Skor pretest } & =\text { skor awal } \\
\text { Skor ideal } & =\text { skor maksimum yang bisa dicapai }
\end{array}
$$


Adapun N-Gain ternormalisasi dijelaskan sesuai dengan kriteria pada Tabel 2. Berdasarkan data pada Tabel 2, dapat diketahui bahwa kriteria N-Gain diklasifikasikan ke dalam tiga kriteria yaitu tinggi, sedang, dan rendah.

Tabel 2. Kriteria N-Gain Ternormalisasi

\begin{tabular}{cc}
\hline Rentang Gain Ternormalisasi & Kriteria \\
\hline $\mathrm{g} \geq 0,70$ & Tinggi \\
$0,30 \leq \mathrm{g}<0,70$ & Sedang \\
$\mathrm{g}<0,30$ & Rendah \\
\hline
\end{tabular}

\section{Analisis Statistik Deskriptif}

Statistik deskriptif yaitu statistik yang dipakai dalam menganalisis data dengan menjabarkan data yang telah dikumpulkan dengan tidak bermaksud menyimpulkan secara umum Sugiyono, (dalam Sholikhah, 2016). Pada penelitian ini, analisis statistic deskriptif digunakan untuk menghitung persentase ketercapaian pembelajaran melalui lembar penilaian guru dan siswa di hari pertama dan hari kedua pelaksanaan. Berikut adalah rumus persentase yang digunakan dalam penelitian ini.

$$
\begin{aligned}
& \mathrm{P}=\frac{\mathrm{f}}{\mathrm{n}} \times 100 \% \\
& \text { Keterangan: } \\
& \mathrm{P} \quad=\text { persentase } \\
& \mathrm{f}=\text { responden yang menjawab } \\
& \mathrm{n}=\text { semua responden }
\end{aligned}
$$

\section{HASIL DAN PEMBAHASAN}

Dalam penelitian ini, pengumpulan data diproses melalui skala Guttman yaitu skala yang berasal dari jawaban tegas seperti jawaban salah-benar, tidak pernah-pernah, setuju-tidak setuju dan iya-tidak. Penggunaan skala Guttman bertujuan untuk mengetahui peran guru dan siswa dalam implementasi Model Pembelajaran Inkuiri Sosial (MPIS). Adapun data hasil lembar penilaian guru hari pertama terlihat di Tabel 3 .

Berdasarkan data dari Tabel 3, diketahui bahwa hasil penilaian guru mengindikasikan skor total sebesar $75 \%$. Hal ini menunjukkan bahwa kategori tersebut termasuk cukup dikarenakan memenuhi kriteria $\geq 50 \%$ dan dinyatakan kurang bila skor $\leq 50 \%$. Data dari Tabel 3 juga memperlihatkan hasil penilaian guru hari pertama dalam mengimplementasikan model pembelajaran inkuiri sosial. Dari kelima aspek penilaian guru ternyata aspek pertama yakni pra pembelajaran dengan dua indikator dan aspek ketiga yakni inti dengan lima indikator dapat dilaksanakan dengan baik. Hal ini disebabkan karena sebelum guru memulai dengan mengimplementasikan model inkuiri sosial, guru dan peneliti berdiskusi dan melakukan perancangan awal sebelum model diimplementasikan. Hal ini telah berdampak pada penguasaan guru terhadap implementasi model inkuiri sosial secara baik. 
Tabel 3. Hasil Lembar Penilaian Guru Hari Pertama

\begin{tabular}{|c|c|c|c|c|}
\hline No & Aspek & Ya & Tidak & $\begin{array}{c}\text { Nilai } \\
\text { Keseluruhan }\end{array}$ \\
\hline 1 & $\begin{array}{l}\text { Pra pembelajaran } \\
\text { (Penyiapan Ruangan, Alat dan Media Pembelajaran) }\end{array}$ & 1 & - & 1 \\
\hline 2 & $\begin{array}{l}\text { Awal pembelajaran } \\
\text { (Berdoa, Pelaksanaan Literasi, Absensi, Apersepsi } \\
\text { dan Motivasi, Mengulas Kembali Pembelajaran, } \\
\text { Menginformasikan Tujuan Pembelajaran) }\end{array}$ & 4 & 2 & 6 \\
\hline 3 & $\begin{array}{l}\text { Inti } \\
\text { (Penyampaian Sintaks MPIS, Mengaitkan Materi } \\
\text { dengan Pengalaman siswa, Membagi siswa dalam } \\
\text { kelompok, Membimbing siswa dalam melakukan } \\
\text { kegiatan dan Mendiskusikan Hasil) }\end{array}$ & 5 & - & 5 \\
\hline \multirow[t]{4}{*}{4} & $\begin{array}{l}\text { Menutup Pelajaran } \\
\text { (Memberikan Penguatan, Evaluasi Akhir, Refleksi, } \\
\text { Salam Penutup) }\end{array}$ & 2 & 2 & 4 \\
\hline & Total & 12 & 4 & 16 \\
\hline & Rata-rata & & 1 & \\
\hline & Persentase & & $75 \%$ & \\
\hline
\end{tabular}

Pada penilaian pertama, ditemukan beberapa kendala guru dalam mengembangkan model inkuiri sosial dengan baik. Hal ini dapat terlihat dari aspek kedua yakni awal pembelajaran dengan enam indikator, yang berhasil dilaksanakan oleh guru yakni empat indikator sementara dua indikator yakni literasi awal dan mengulas kembali pembelajaran yang lalu tidak dapat dilaksanakan dengan baik. Sementara aspek keempat yakni menutup pembelajaran yang terdiri dari empat indikator, dimana dua indikator yakni memberikan penguatan dan refleksi tidak dapat dilaksanakan oleh guru. Tidak terlaksananya indikator-indikator tersebut disebabkan oleh guru yang masih belum terbiasa dalam mengimplementasikan model inkuiri sosial pada pembelajaran IPS di kelas V MI Salman Al-Farisi.

Selain lembar penilaian guru, peneliti juga melakukan penilaian terhadap terdapat peran siswa dalam implementasi model pembelajaran inkuiri sosial. Hasil penilaian siswa hari pertama dapat terlihat pada Tabel 4. Berdasarkan data pada Tabel 4, diketahui bahwa skor akhir menunjukkan angka $71 \%$, sehingga dapat dikategorikan bahwa skor tersebut termasuk dalam kategori cukup.

Sebelum model pembelajaran inkuiri sosial diimplementasikan pada hari kedua, peneliti dan guru melakukan refleksi dan perencanaan untuk mempersiapkan implementasi pada hari kedua. Refleksi dan perencanaan dibuat untuk memperoleh masukan dalam merancang dengan tujuan untuk memperbaiki implementasi model inkuiri sosial pada pertemuan kedua. Capaian pembelajaran guru pada hari kedua, dapat terlihat pada Tabel 5.

Pada pertemuan hari kedua menunjukan terjadi peningkatan presentasi peran guru dalam implementasi model inkuiri sosial, dimana pada hari pertama presentasi keberhasilan guru mencapat $75 \%$ sementara pada hari kedua peran guru dalam implementasi model mencapai $87 \%$. Pencapaian keberhasilan ini sejalan dengan terpenuhinya hamper semua indikator peran guru dalam implementasi model. Hanya terdapat dua indikator yang belum dilaksanakan oleh guru yakni 
mengulas kembali pembelajaran yang lalu dan refleksi di akhir pembelajaran. Hal ini disebabkan karena banyaknya indikator keterlaksanaan model sehingga memungkinkan guru lupa mengimplementasikan dua indikator tersebut.

Tabel 4. Hasil Lembar Penilaian Siswa Hari Pertama

\begin{tabular}{|c|c|c|c|c|}
\hline No & Aspek & Ya & Tidak & $\begin{array}{c}\text { Nilai } \\
\text { Keseluruhan }\end{array}$ \\
\hline 1 & $\begin{array}{l}\text { Keaktifan } \\
\text { (Aktif Memperhatikan Penjelasan Guru, Menjawab } \\
\text { Pertanyaan Guru, Keaktifan dan Inisiatif, } \\
\text { Mengerjakan tugas individu) }\end{array}$ & 3 & 1 & 4 \\
\hline 2 & $\begin{array}{l}\text { Keberanian } \\
\text { (Rasa Ingin Tahu, Keberanian Siswa) }\end{array}$ & 2 & - & 2 \\
\hline 3 & $\begin{array}{l}\text { Kerjasama } \\
\text { (Berbagi Pendapat dan Ide, Kerja Kooperatif) }\end{array}$ & 1 & 1 & 2 \\
\hline 4 & $\begin{array}{l}\text { Bertanya } \\
\text { (Mengajukan Pertanyaan dengan Sopan) }\end{array}$ & 1 & - & 1 \\
\hline 5 & $\begin{array}{l}\text { Kemampuan } \\
\text { (Merumuskan Masalah, Membuat Hipotesis, } \\
\text { Mengumpulkan data, Menguji Hipotesis dan } \\
\text { Membuat Kesimpulan) }\end{array}$ & 3 & 2 & 5 \\
\hline & Total & 10 & 4 & 14 \\
\hline & Rata-rata & \multicolumn{3}{|c|}{1} \\
\hline & Persentase & \multicolumn{3}{|c|}{$71 \%$} \\
\hline
\end{tabular}

Tabel 5. Hasil Lembar Penilaian Guru Hari Kedua

\begin{tabular}{|c|c|c|c|c|}
\hline No & Aspek & Ya & Tidak & $\begin{array}{c}\text { Nilai } \\
\text { Keseluruhan }\end{array}$ \\
\hline 1 & $\begin{array}{l}\text { Pra pembelajaran } \\
\text { (Penyiapan Ruangan, Alat dan Media Pembelajaran) }\end{array}$ & 1 & - & 1 \\
\hline 2 & $\begin{array}{l}\text { Awal pembelajaran } \\
\text { (Berdoa, Pelaksanaan Literasi, Absensi, Apersepsi } \\
\text { dan Motivasi, Mengulas Kembali Pembelajaran, } \\
\text { Menginformasikan Tujuan Pembelajaran) }\end{array}$ & 5 & 1 & 6 \\
\hline 3 & $\begin{array}{l}\text { Inti } \\
\text { (Penyampaian Sintaks MPIS, Mengaitkan Materi } \\
\text { dengan Pengalaman siswa, Membagi siswa dalam } \\
\text { kelompok, Membimbing siswa dalam melakukan } \\
\text { kegiatan dan Mendiskusikan Hasil) }\end{array}$ & 5 & - & 5 \\
\hline 4 & $\begin{array}{l}\text { Menutup Pelajaran } \\
\text { (Memberikan Penguatan, Evaluasi Akhir, Refleksi, } \\
\text { Salam Penutup) }\end{array}$ & 3 & 1 & 4 \\
\hline & Total & 14 & 2 & 16 \\
\hline & Rata-rata & \multicolumn{3}{|c|}{1} \\
\hline & Persentase & \multicolumn{3}{|c|}{$87 \%$} \\
\hline
\end{tabular}

Peran guru dalam implementasi model pembelajaran inkuiri sosial ternyata memiliki korelasi dengan hasil pencapaian hasil peran siswa dalam implementasi model. Pada hari pertama, peran siswa mencapai $71 \%$ sementara pada hari kedua, peran siswa dalam implementasi model mencapai $85 \%$, dimana terdapat satu indikator yang belum dapat dilaksanakan dengan baik yakni menguji hipotesis. Hal ini disebabkan karena setelah selesai mempresentasikan hasil pengumpulan data, siswa langsung menarik kesimpulan akhir tanpa melihat kembali hipotesis yang telah dirumuskan 
untuk dibuktikan kebenarannya berdasarkan data yang diperoleh di lapangan. Pencapaian peran siswa dalam implementasi model dapat terlihat pada Tabel 6.

Tabel 6. Hasil Lembar Penilaian Siswa Hari Kedua

\begin{tabular}{|c|c|c|c|c|}
\hline No & Aspek & Ya & Tidak & $\begin{array}{c}\text { Nilai } \\
\text { Keseluruhan }\end{array}$ \\
\hline 1 & $\begin{array}{l}\text { Keaktifan } \\
\text { (Aktif Memperhatikan Penjelasan Guru, Menjawab } \\
\text { Pertanyaan Guru, Keaktifan dan Inisiatif, } \\
\text { Mengerjakan tugas individu) }\end{array}$ & 4 & - & 4 \\
\hline 2 & $\begin{array}{l}\text { Keberanian } \\
\text { (Rasa Ingin Tahu, Keberanian Siswa) }\end{array}$ & 2 & - & 2 \\
\hline 3 & $\begin{array}{l}\text { Kerjasama } \\
\text { (Berbagi Pendapat dan Ide, Kerja Kooperatif) }\end{array}$ & 2 & - & 2 \\
\hline 4 & $\begin{array}{l}\text { Bertanya } \\
\text { (Mengajukan Pertanyaan dengan Sopan) }\end{array}$ & 1 & - & 1 \\
\hline 5 & $\begin{array}{l}\text { Kemampuan } \\
\text { (Merumuskan Masalah, Membuat Hipotesis, } \\
\text { Mengumpulkan data, Menguji Hipotesis dan } \\
\text { Membuat Kesimpulan) }\end{array}$ & 4 & 1 & 5 \\
\hline & Total & 13 & 1 & 14 \\
\hline & $\begin{array}{l}\text { Rata-rata } \\
\text { Persentase }\end{array}$ & & $\begin{array}{c}1 \\
85 \%\end{array}$ & \\
\hline
\end{tabular}

Berdasarkan hasil penilaian guru dan siswa dalam implementasi model inkuiri sosial di atas, dapat dijelaskan bahwa model pembelajaran inkuiri sosial dapat meningkatkan peran siswa dan guru dalam pembelajaran IPS di kelas V MI Salman Al-Farisi. Hal ini dibuktikan dengan peningkatan persentase dari $75 \%$ menjadi $87 \%$ terkait dengan penilaian guru. Pada aspek penilaian siswa, peningkatan yang terjadi sebesar $14 \%$ dari semula penilaian hanya $71 \%$.

Adapun penerapan model pembelajaran inkuiri sosial dalam peningkatan kecerdasan sosial pada siswa di kelas V siswa MI Salman Al-Farisi Liang peneliti menggunakan angket. Pedoman penilaian pada lembar angket siswa menggunakan skala likert dengan macam pilihan jawaban antara 1-5. Penggunaan skala likert bertujuan untuk mengetahui peningkatan kecerdasan sosial siswa. Untuk mengukur kecerdasan sosial siswa melalui implementasi model inkuiri sosial, peneliti merumuskan lima aspek yakni 1). Kesadaran diri [KS], 2). Mampu bekerjasama dengan orang lain [MBL], 3). Berempati [BE], 4). Mampu berkomunikasi [MB], dan 5). Mampu memecahkan masalah [MMM]. Adapun hasil rata-rata N-Gain setiap indikator kecerdasan sosial siswa disajikan pada Tabel 7.

Sesuai Tabel 7, hasil rata-rata pada aspek Kesadaran Diri adalah 0,39 dengan kriteria Sedang. Pada aspek Mampu Bekerjasama dengan Orang Lain rata-ratanya adalah 0,35 dengan kriteria Sedang. Pada aspek Mampu Berkomunikasi rata-rata yang diperoleh adalah 0,41 termasuk dalam kriteria Sedang. Pada aspek Berempati rata-rata yang diperoleh adalah 0,29 termasuk dalam kriteria Rendah. Pada aspek Mampu Memecahkan Masalah, rata-rata siswa memperoleh 0,70 dengan kriteria Tinggi. Pencapaian aspek KS, MBL, MB dan MMM mencapai hasil yang baik yakni berada 
pada kategori sedang dan tinggi, sementara aspek BE yang terdiri dari indikator rasa peduli, tenggang rasa dan intuisi tinggi masih memperoleh kategori rendah. Perolehan kategori rendah pada aspek BE disebabkan karena kepercayaan diri yang dimiliki oleh masing-masing siswa yang menganggap pikiran dan pendapatnya lebih benar jika dibandingkan dengan orang lain. Sikap intuisi yang berlebihan selama ini telah menempatkan sebagian makhluk individu yang sangat protek dalam membangun relasi dengan orang lain.

Pada aspek kesadaran diri dengan rata-rata 0,39 siswa memiliki tingkat kesadaran diri yang sedang sesuai dengan perkembangan anak yang sudah bisa mengendalikan emosinya, tetapi sering mengalami rasa tidak percaya diri dan mood swing. Sehingga pada integritas diri anak sudah mulai tercipta rasa kejujuran, kepercayaan, dan kehormatan diri. Selain itu anak juga sudah mulai bisa menyelesaikan permasalahan dan pandai bernegosiasi. Rasa percaya diri adalah salah satu bagian dari kepribadian diri yang jadi faktor internal dalam pribadi setiap anak (Asiyah dkk., 2019). Kepercayaan diri siswa berdasarkan pengamatan awal di MI Salman Al-Farisi ditemukan masih dalam kategori sedang sikap percaya diri siswa.

Tabel 7. Rerata N-Gain Setiap Indikator Kecerdasan Sosial

\begin{tabular}{cllcc}
\hline No & Aspek & \multicolumn{1}{c}{ Indikator } & N-Gain & \multicolumn{1}{c}{ No. Soal } \\
\hline 1 & KS & Mengontrol Diri, Percaya Diri, Integritas Diri & 0,39 & $1,2,3,4,5,6$ \\
2 & MBL & $\begin{array}{l}\text { Bertanggung Jawab, Berkolaborasi, Mudah } \\
\text { Bergaul }\end{array}$ & 0,35 & $7,8,9,10,11,12$ \\
& & Rasa Peduli, Tenggang Rasa, Intuisi Tinggi & 0,29 & $13,14,15,16,17,18$ \\
3 & BE & Tutur Kata, Berekspresi, Presentasi & 0,41 & $19,20,21,22,23,24$ \\
4 & MB & Kreatif, Inovatif, Semangat Tinggi & 0,70 & $25,26,27,28,29,30$ \\
\hline
\end{tabular}

Keterangan:

KS : Kesadaran Diri

MBL : Mampu Bekerjasama dengan Orang Lain

BE : Berempati

MB : Mampu Berkomunikasi

MMM : Mampu Memecahkan Masalah

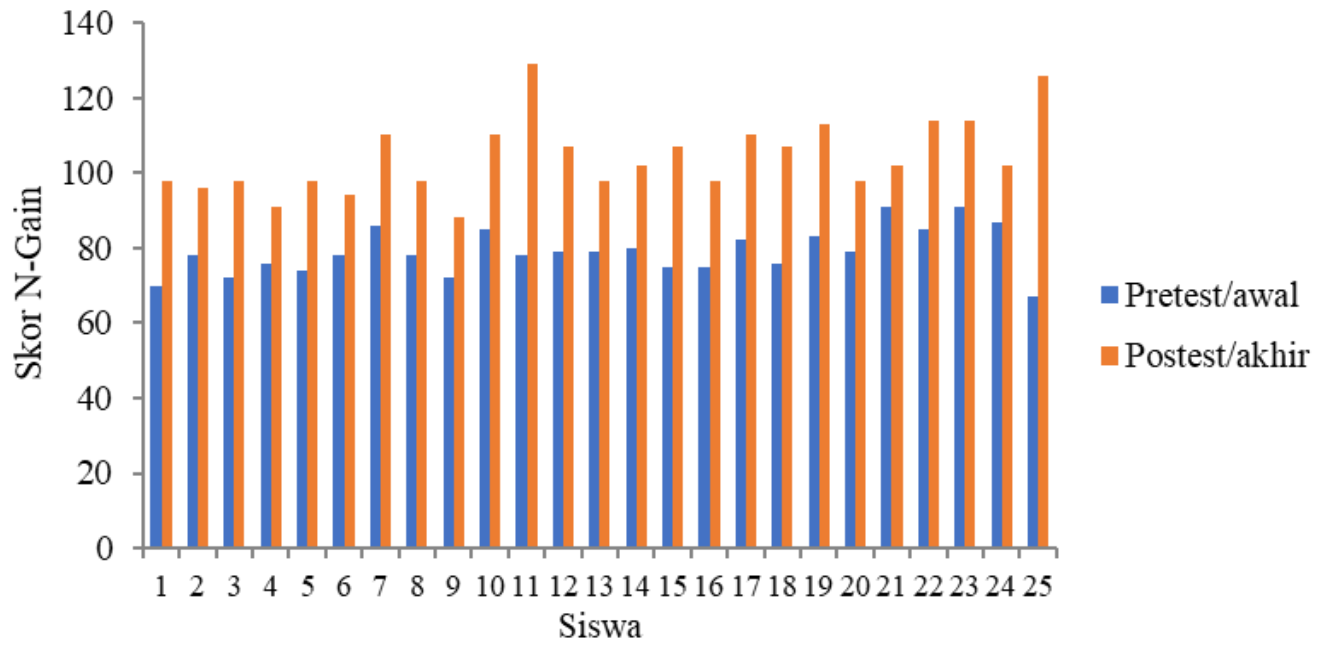

Gambar 1. Hasil Pretest-Postest Kecerdasan Sosial Siswa 
Gambar 1 menunjukkan terdapat 10 siswa dengan kriteria kecerdasan sosial rendah, 13 siswa mendapatkan kriteria cerdas sosial sedang, dan 2 siswa mendapatkan kriteria cerdas sosial tinggi. Terkait dengan simpulan umum, dapat dikatakan bahwa penerapan model pembelajaran inkuiri sosial dapat meningkatkan kecerdasan sosial. Hal tersebut sesuai dengan hasil data penelitian secara signifikan ketika angket dibagikan sebelum menerapkan model pembelajaran inkuiri sosial rata-rata hasilnya adalah 79,04. Rata-rata hasil tersebut didapatkan dari jumlah seluruh pretest siswa dan dibagi dengan jumlah keseluruhan siswa dan setelah penerapan model pembelajaran inkuiri sosial rata-rata hasilnya adalah 104,32.

Model pembelajaran inkuiri sosial yang diterapkan dalam proses pembelajaran dengan rata-rata lembar penilaian guru dan siswa masing-masing mengalami peningkatan pada hari kedua. Hal ini bukan hal baru, sebab pada kurikulum Kurikulum 13 saat ini siswa selalu diajak untuk mengeksplorasi atau menemukan sendiri permasalahan yang terjadi dan belajar untuk memecahkan masalah tersebut. Guru sebagai fasilitator, mengarahkan siswa dan membimbing siswa dalam proses kegiatan tetapi tidak membantu siswa dalam menemukan jawaban atau solusi.

Proses pembelajaran dengan menerapkan model inkuiri sosial sangat membantu guru maupun siswa dalam melakukan kegiatan eksplorasi pada Tema Lingkungan Sahabat Kita dengan sub tema Manusia dan Lingkungan pada pembelajaran 4. Guru menerapkan enam tahapan dengan cukup baik dengan memberikan contoh yang abstrak dan konkret sesuai dengan kondisi perkembangan kognitif siswa. Selain itu juga guru membawa siswa dalam lingkungan untuk membuat anak menjadi semangat dan bebas melakukan kreativitas anak dalam mengerjakan tugas dalam tim. Begitu pula dengan siswa yang bersemangat dan mampu melaksanakan proses belajar mengajar dengan cukup baik.

Saat ini banyak siswa yang memiliki kemampuan bertanya dan memberikan pendapat meski masih malu-malu. Namun jika diberikan kesempatan bertanya ataupun berpendapat mereka mau mengetahui berpendapat itu seperti apa. Selain itu juga siswa mau bertanya ke teman sebangku saat diberikan angket mengenai pernyataan yang belum dipahami. Dari pengamatan itu disimpulkan bahwa siswa MI Salman Al-Farisi Liang sudah tertanam sikap rasa percaya diri dalam siswa. Namun belum dibiasakan untuk mengasah rasa percaya terhadap diri siswa itu sendiri. Berdasarkan hal itu, sejalan dengan yang ditulis oleh Novena \& Kriswandani (2014) yang menyebutkan bahwa rasa percaya diri yang dimiliki belum tinggi karena belum ada pembiasaan.

Adapun aspek mampu bekerjasama dengan orang lain siswa kelas V MI Salman Al-Farisi masih tergolong sedang dengan rata-rata 0,35 karena tidak terlepas dari faktor keluarga juga. Orang tua memiliki tanggung jawab untuk mendidik, memberikan bimbingan, dan melatih anak agar menjadi cerdas, sehingga setiap anak dapat meningkatkan kecerdasan sosial dalam berinteraksi dengan orang lain. Pola asuhan setiap orang tua berbeda-beda terhadap anaknya, maka hasil dari 
pola asuh yang berbeda dalam mengembangkan kecerdasaan sosial terhadap anak juga akan memberi dampak yang berbeda pula. Menurut Robbiyah dkk. (2018) terdapat 3 macam pola asuh orang tua untuk mendidik anaknya dalam proses untuk mengembangkan kecerdasaan sosialnya yaitu pola asuh otoritatif, permisif, dan otoriter.

Ginsburg dan Silakoswki (dalam Fidrayani, 2015) dalam penelitiannya menyatakan bahwa tingkat empati yang sangat rendah yaitu sikap mementingkan diri sendiri di atas kepentingan orang lain. Hal ini terjadi karena adanya rasa tidak peduli dengan sesama dan diabaikan dalam kelompok sosial. Pernyataan tersebut membuktikan bahwa dari hasil penelitian ini dalam aspek berempati yang meliputi rasa peduli, tenggang rasa, dan intuisi tinggi, masih dalam kriteria Rendah dengan rata-rata skor N-gain adalah 0,29. Sehingga menurut Roslina (dalam Fidrayani, 2015) pengembangan empati salah satunya dapat dilaksanakan dengan memasukkan aspek berempati dalam proses pembelajaran setiap hari dan beberapa penyebab kurangnya empati yaitu ancaman atau hukuman fisik.

Pada aspek mampu berkomunikasi, dengan tiga indikator antara lain tutur kata, berekspresi, dan presentasi (kejelasan vokal). Siswa kelas V MI Salman Al-Farisi Liang, memperoleh nilai skor $\mathrm{N}$-Gain adalah 0,41 termasuk dalam kriteria sedang. Beberapa faktor yang mempengaruhi yakni kemampuan berkomunikasi siswa di kelas V. Pada usia tersebut siswa sudah mulai mengalami masa pertumbuhan ke tahap dewasa yang mengakibatkan cara berkomunikasi mereka mengalami perbaikan, namun juga masih terdapat siswa yang masih menggunakan bahasa sehari-hari yang juga dipengaruhi oleh lingkungan dan pergaulan teman. Helti (2016) menjelaskan bahwa selain kematangan organ suara bagi siswa laki-laki faktor yang membuat anak memiliki komunikasi yang minim dipengaruhi oleh tekanan orang sekitarnya. Selain itu, bahasa ibu sangat mempengaruhi proses berkembangnya komunikasi anak. Peristiwa tersebut terjadi karena faktor lingkungan yang mendominasi penggunaan bahasa daerah setempat. Untuk mengatasi masalah tersebut, maka guru pada saat proses belajar berlangsung harus menggunakan bahasa Indonesia benar (Putro, 2017).

Pada aspek memecahkan masalah, kecerdasan sosial siswa termasuk dalam kriteria tinggi dengan rata-ratanya adalah 0,70 . Hal ini disebabkan pada indikatornya yaitu kreatif, inovatif, dan semangat tinggi. Pada indikator kreatif siswa kelas V MI Salman Al-Farisi Liang, sudah mampu mengumpulkan data dengan mewawancarai, ada yang melakukan pengamatan, dan ada pula yang mengambil dokumentasi dengan kreatif mereka sendiri. Indikator inovatif, siswa sangat antusias dalam mencoba hal-hal yang baru diajarkan oleh guru. Indikator semangat tinggi, siswa sangat bersemangat dalam mengumpulkan data dan mengambil dokumentasi. Sehingga, peneliti tidak hanya sekedar melihat sikap anak akan tetapi lebih dari itu yaitu untuk kehidupan masa depan anak. Menurut Erlina (2016) siswa memiliki kecerdasan sosial yang tinggi, dapat terlihat dari kemampuan siswa dalam bersosialisasi dan beradaptasi dengan siswa dalam lingkungan sosial serta memiliki 
sikap terbuka dalam melihat permasalahan yang terjadi. Selain itu, orang dengan kecerdasan sosial yang tinggi dapat terlihat pada kemampuan mereka dalam berkomunikasi baik.

\section{SIMPULAN DAN SARAN}

\section{Simpulan}

Implementasi model pembelajaran inkuiri sosial mendapat pengaruh positif terhadap kecerdasan sosial siswa kelas V MI Salman Al-Farisi dan dapat diterapkan dengan cukup baik oleh guru kelas V MI Salman Al-Farisi. Peningkatan hasil kecerdasan sosial melalui model pembelajaran inkuiri sosial pada siswa kelas V MI Salman Al-Farisi rata-rata berada pada kategori rendah dan sedang. Analisis hasil setiap indikator kecerdasan sosial siswa dengan mengimplementasikan model inkuiri sosial dapat menjadi acuan dalam meningkatkan kecerdasan sosial siswa menjadi lebih baik. Sehingga faktorfaktor yang mempengaruhi ke lima aspek kecerdasan sosial siswa dapat teratasi dengan maksimal.

\section{Saran}

Diharapkan guru bisa menerapkan model pembelajaran inkuiri sosial ini di kelas ataupun di luar kelas, sehingga kecerdasan sosial siswa kelas V MI Salman Al-Farisi Liang dapat meningkat. Diharapkan siswa dapat memiliki kecerdasan sosial yang dapat digunakan dalam hidup bermasyarakat, berbangsa dan bernegara. Peranan orangtua, guru, dan pemerintah sangat membantu dalam meningkatkan kecerdasan sosial siswa.

\section{DAFTAR RUJUKAN}

Alfina, R. U., H, Y., \& Rapani. (2018). Pengaruh Model Pembelajaran Inkuiri Sosial terhadap Hasil Belajar IPS Siswa Renita. Pedagogi: Jurnal Pendidikan Dasar, 8(5).

Amiluddin, R., \& Sugiman, S. (2016). Pengaruh Problem Posing dan PBL Terhadap Prestasi Belajar, dan Motivasi Belajar Mahasiswa Pendidikan Matematika. Jurnal Riset Pendidikan Matematika, 3(1), 100-108.

Asiyah, Walid, A., \& Kusumah, R. G. T. (2019). Pengaruh Rasa Percaya Diri Terhadap Motivasi Berprestasi Siswa pada Mata Pelajaran IPA. Scholaria: Jurnal Pendidikan dan Kebudayaan, 9(3), 217-226.

El-Banjary, J. (2013). Inspiring Teacher 1 (7 Zona Pemantik Sukses Menjadi Guru Inspiratif). PT Elex Media Komputindo.

Erlina. (2016). Pengaruh Metode Pembelajaran Dan Kecerdasan Sosial Terhadap Hasil Belajar Pendidikan Kewarganegaraan Siswa Kelas V Sekolah Dasar. Jurnal Pendidikan Dasar, 7(1), 27-37.

Fidrayani. (2015). Pengembangan Empati Pada Anak Usia Sekolah Dasar. 125-130.

Hasan, S. H. (2010). Revitalisasi Pendidikan IPS dan Ilmu Sosial Untuk Pembangunan Bangsa (Ed. Suryadi Karim dan Malihah Elly, Ed.). Rizqi Press dan FPIPS UPI.

Helti, Y. (2016). Karakteristik Perkembangan Bahasa Anak SD dalam Berkomunikasi. Jurnal Cerdas Proklamator, 4(1), 9-21.

Kowendha, E. (2016). Penerapan Model Pembelajaran Basic Learning untuk Meningkatkan Kerjasama dan Hasil Belajar Siswa Kelas IV SD Negeri 4 Galanggang. Universitas Pattimura. 
Kusumaningrum, E. (2016). Perbedaan Perilaku Prososial dan Self Awareness Terhadap Nilai Budaya Lokal Jawa di Tinjau Dari Jenis Kelamin Pada Siswa Sma Kyai Ageng Basyariyah Kecamatan Dagangan Kabupaten Madiun. Jurnal Ilmiah Counsellia, 6(2), 17-30.

Kusumawati, P. N., \& Manutede, Y. Z. (2018). Pendekatan Bimbingan Kelompok Tehnik Analisis

Transaksional untuk Meningkatkan Kecerdasan Sosial pada Anak-Anak Di Panti Asuhan Sejahtera Tobelo Kabupaten Halmahera Utara. Jurnal Uniefera, 7(2), 77.

Mahananingtyas, E. (2018). Pendekatan Konstruktivis Sosial Dalam Peningkatan Hasil Belajar IPS di SD Kelas IV. Jurnal Pedagogika dan Dinamika Pendidikan, 6(1), 34-44.

Mahananingtyas, E., Ritiauw, S. P., \& Siahaya, A. M. (2020). Peningkatan Nilai-Nilai Karakter dan Hasil Belajar IPS Melalui Model Pembelajaran Numbered Head Together Pada Siswa Kelas V SD Inpres 19 Ambon. Jurnal Pedagogika dan Dinamika Pendidikan, 8(1), 24-37.

Nasehudin. (2016). Keluarga Dalam Lingkungan Pendidikan Manusia Mandiri. Edueksos, 5(1), 23-35.

Novena, V. V., \& Kriswandani. (2014). Pengaruh Model Pembelajaran Probing Prompting Terhadap Hasil Belajar Ditinjau Dari Self-Efficacy. Scholaria: Jurnal Pendidikan dan Kebudayaan, 8(23), 189-196.

Pradana, P. H., \& Masyitoh, D. (2018). Upaya Peningkatan Kecerdasan Sosial dan Emosional Anak Usia Dini dalam Pendidikan Islam. 5(1).

Putro, K. Z. (2017). Memahami Ciri dan Tugas Perkembangan Masa Remaja. APLIKASIA: Jurnal Aplikasi Ilmu-ilmu Agama, 17(1), 25-32.

Rahmawati, A. (2016). Tingkat Kecerdasan sosial Siswa Dalam Pembelajaran IPS Kelas V SDN di Kecamatan Mejobo Kabupaten Kudus (Doctoral dissertation, Universitas Negeri Semarang).

Ramdhani, N. (2016). Emosi Moral dan Empati pada Pelaku Perundungan-siber. Jurnal Psikologi, 43(1), 66-80.

Ritiauw, S. P., Maftuh, B., \& Malihah, E. (2018). Model of Conflict Resolution Education Based on Cultural Value of "Pela" in Social Studies Learning. 147(Icsse 2017), 289-299.

Ritiauw, S. P., \& Salamor, L. (2016). Mengembangkan Keterampilan Berpikir Kritis Siswa Sekolah Dasar Melalui Implementasi Model Pembelajaran Sosial Inkuiri. Jurnal Pedagogika dan Dinamika Pendidikan, 4(1), 42-56.

Robbiyah, Ekasari, D., \& Witarsa, R. (2018). Pengaruh Pola Asuh Ibu terhadap Kecerdasan Sosial Anak Usia Dini di TK Kenanga Kabupaten Bandung Barat. Jurnal Obsesi: Jurnal Pendidikan Anak Uisa Dini, 2(1), 76-84.

Salam, R. (2017). Model Pembelajaran Inkuiri Sosial Dalam Pembelajaran IPS. Harmony, 2(1), 7-12. Sholikhah, A. (2016). Statistik Deskriptif Dalam Penelitian Kualitatif. Komunika, 10(2), 342-362.

Surahman, E., \& Mukminan. (2017). Peran Guru IPS Sebagai Pendidik dan Pengajar Dalam Meningkatkan Sikap Sosial dan Tanggung Jawab Sosial Siswa SMP. Harmoni Sosial: Jurnal Pendidikan IPS, 4(1), 1-13.

Susanti. (2018). Manfaat Mata Pelajaran Ilmu Pengetahuan Sosial (IPS) Sejarah terhadap Pembentukan Moral Peserta Didik. Jurnal Pendidikan, 12(1), 14-27.

Utami, I. G. A. L. P. (2016). Teori Konstruktivisme Dan Teori Sosiokultural: Aplikasi Dalam Pengajaranbahasa Inggris. Prasi, 11(01), 4-11.

Vygotsky, L. (1978). Mind in Society: The Development of Higher Psychological Processes. Harvard University Press.

Zakiah, L. (2020). Hubungan Kecerdasan Sosial dan Hasil Belajar Siswa Kelas IV Sekolah Dasar. Jurnal Parameter, 32(1), 30-52. https://doi.org/doi.org/10.21009/parameter.321.03 P-ISSN 